Stellenbosch Theological Journal 2018, Vol 4, No 1, 39-60

DOI: http://dx.doi.org/10.17570/stj.2018.v4n1.a02

Online ISSN 2413-9467 | Print ISSN 2413-9459

2018 (c) Pieter de Waal Neethling Trust

\title{
Towards the implementation of sustainable development goals in Nigeria: Maximizing the influence of religious leaders
}

\author{
Akinloye, Idowu A \\ Rhodes University \\ idakinloye@gmail.com
}

\begin{abstract}
The limited scope of the Millennium Development Goals (MDGs) and the failure of the programme to achieve its developmental objectives at its expiry in 2015 led to the development and implementation of the Sustainable Development Goals (SDGs) programme commencing 2016. The SDGs progamme has been widely accepted as laudable for its wider approach to global development and sustainability. However, if the SDGs programme is not to end as the Millennium Development Goals did, it is necessary that its implementing actors collaborate with stakeholders of institutions that will make more members of the populace aware of, accepting of, and involved in the implementation of the goals. This is crucial because the goals require the populace' corresponding participation. This paper focuses on one such institutional stakeholder: religious leaders. This paper, through literature review and analysis of surveys and reports, examines the influence religious leaders have on their followers in Africa with Nigeria as a case study. It argues that religious leaders have a strong influence on their followers, as Nigerians and most Africans place more trust in, and respect the opinions of their religious leaders than their political counterparts. The paper, therefore, contends that if the global agenda of the SDGs is to be realised by getting a wider Nigerians to accept and involve in the implementation of the sustainable goals, then, the potential influence of religious leaders should be harnessed.
\end{abstract}

Key words

Sustainable development goals; religious leaders; Nigeria; awareness 


\section{Introduction}

The Millennium Development Goals (MDGs) ${ }^{1}$ made many promises for global development. However, for some reasons and limitations, many of its objectives were not achieved at its expiration in 2015. Some scholars (Easterly 2009, Saith 2007, Fehling et al 2013, Munang and Andrews 2014) thought that the goals were limited in reaching out to all the targeted groups. For example, Wysokinska observed that: 'Although significant achievements have been recorded with respect to the MDGs targets worldwide, progress has been uneven across regions and countries, leaving significant gaps. Millions of people are being left behind, especially the poorest and those disadvantaged because of their sex, age, disability, ethnicity, or geographic location' (Wysokinska 2017:106).

As a result of the above limitation, and following the expiry of the MDGs, the world leaders through the United Nations involving its 193 member States gathered on the 25 September 2015 in New York to chart another course towards global development. This birthed the Sustainable Development Goals (SDGs) to replace the MDGs programme. The SDGs became operational in 2016 and the programme is expected to end by 2030 .

Scholars like Nilsson and Costanza, and Gurbo have accepted the SDGs programme as laudable because it is more inclusive, universal, and creates global partnerships based on the joint responsibility and obligations of all partners (Nilsson and Costanza 2015, Gurbo 2017). However, as much as it has been lauded, the programme is not without its criticisms. It has been argued that the SDGs programme only aims to change the world without transforming it (Hickel 2015). Raquel et al also argue that despite the United Nations adoption of the goals, a framework for operationalising them in an integrated way is lacking (Nunes et al 2016).

1 The Millennium Development Goals (MDGs) are contained in the Millennium Declaration of 2000, ratified at a summit of 189 Member States of the United Nations. The eight millennium goals contained in the Declaration constitute obligations on the part of the international community to: 1) Eradicate extreme poverty and hunger; 2) Achieve universal primary education; 3) Promote gender equality and empower women; 4) Reduce child mortality; 5) Improve maternal health; 6) Combat HIV/AIDS, malaria, and other diseases; 7) Ensure environmental sustainability; and 8) Develop a global partnership for development. The deadline for achieving these goals was set forth in the Declaration as the year 2015. 
The focus of this paper is neither to analyse the contents of the SDGs nor to engage in the arguments for or against the programme. Rather, the thesis of this paper is to appraise and examine how the implementing actors of the programme in Nigeria and in the other African States can effectively mobilise and create awareness about the SDGs through collaboration with religious leaders. The paper is also proffering effective ways through which the influence of religious leaders may be harnessed in implementing these goals in a manner that will not infringe on the religious rights of the citizens, particularly where there might be conflicts between the sustainable principles and religious practices. Certain limitations that may be faced in this line are to be highlighted.

This paper is divided into seven sections. The first is the introduction, followed by a brief discussion on the nature and components of the SDGs. The third section highlights the implementation strategy of the SDGs in Nigeria, focusing on the official implementing actor, the Office of the Special Assistant to the President on Sustainable Development Goals. The fourth section discusses the need to sensitise Nigerians about the SDGs initiatives. The next section discusses how the influence of religious leaders in Nigeria can be harnessed to facilitate the implementation of the SDGs through effective sensitisation. The sixth section takes a critical look by highlighting the challenges that may be faced in assessing the religious leaders' potentials in the implementation of the SDGs. The last section gives a summary and draws the conclusion.

\section{Meaning and components of SDGs}

The SDGs are also referred to as 'Transforming our World: The 2030 Agenda for Sustainable Development' (United Nations 2015) or the 'Global Goals'. The concept of the SDGs was raised for the first time at the United Nations Conference on Sustainable Development in 2012. One of the objectives was to produce a set of universally applicable goals that will balance the three dimensions of sustainable development, that is, environmental, social, and economic. The SDGs is a set of 17 global goals ${ }^{2}$ with 169 targets

2 United Nations - General Assembly, 2015,'Transforming Our World: The 2030 Agenda for Sustainable Development' [Online]. Available: http://www.un.org/ga/search/view_doc. asp?symbol=A/RES/70/1\&Lang=E [Accessed: 11 October 2017].The goals are: No poverty; Zero 
between them. The programme aims to guide policy and funding for the next 15 years, that is, 2015 to 2030 and beginning with a significant undertaking to end poverty everywhere permanently. The goals are built on the lessons learned from the MDGs especially, the MDGs' failure to address the structural causes of poverty, inequality and exclusion, as well as environmental sustainability. Consequently, in comparison to the MDGs, the new programme contains series of additional elements to the main aspects of sustainable development agenda that apply to all countries, such as encouraging peaceful and inclusive societies, realising the human rights of all, achieve gender equality in all spheres of life, create better jobs and deal with the environmental challenges of our time, particularly climate change. Moreover, a number of the SDGs do not only simply specify the outcome goals, but also the means by which these goals are to be achieved. The SDGs are expected to complete the job that the MDGs started, and to leave no one behind.

\section{Implementation of SDGs in Nigeria}

Nigeria is one of the nations that endorsed the MDGs as well as the SDGs. The MDGs which started in 2000 did not however commence in Nigeria until 2005 after the cancellation of the debt relief in favour of the country. The cancellation of the debt enabled the government to save about US\$1 billion annually (Durokifa and Abdul-wasi 2016). During the era of the implementation of the MDGs in Nigeria, a number of steps were taken that included the release of funds to carry out some propoor interventions programmes such as, the Conditional Cash Scheme, National Economic Empowerment and Development Strategy (NEEDS), etc. The NEEDS for instance, is a reform programme to lay a foundation for sustainable poverty reduction, employment generation, wealth creation and value re-orientation. As a way of bringing the reform programme closer to Nigerians, each federating state was expected to develop a State Economic Empowerment and Development Strategy (SEEDS) (Ajiye 2014).

hunger, good healthy; quality education; gender equality; clean water and sanitation; Affordable and clean energy; Decent work and economic growth; Infrastructure and industrialization; Reduce inequality; Sustainable cities; Responsible consumption and production; Climate action; Life below water; Live on Land; Peace, justice and strong institutions; and Partnerships. 
MDGs project in Nigeria was reported to have gulped about 1.4 trillion Nigerian Naira between 2006 and 2010 (Az-Zubair 2010). Some scholars have however observed that despite all the government did towards the realisation of the MDGs in Nigeria, the country is still among the nations that failed to meet the 2015 MDGs targets. (Oloribe 2016, Durokifa and Abdul-wasi 2016; Nigeria MDGs Report 2015).

Consequently, towards achieving the SDGs, the present administration of President Buhari has affirmed support for the SDGs programme to avoid repeating the failure of the MDG processes. Accordingly, the SDGs initiative has been adopted as a federal government programme that comprises of different levels of staff deployed from various relevant federal government ministries. In addition, the office of the Senior Special Assistant to the President on Sustainable Development Goals (SSAPSDGs) was reconstituted and designated as the major implementing actor of the programme. The SSAP-SDGs is accountable to the Presidential Advisory Committee headed by the President of Nigeria. The mandate of the SSAP-SDGs includes providing leadership and guidance on the SDGs, coordinating and integrating the SDGs into Nigeria's national development plans, and developing an actionable framework for implementation at the national, state and local government levels. The SSAP-SDGs is also to consult regularly with all key stakeholders such as the public sector, state governments, local governments, civil society organisations, private sectors, amongst others. Also, the SSAP-SDGs is required to engage in collaboration across sectors in the implementation, monitoring, and reporting of the SDGs and providing regular sensitisation on SDGs' activities to the general public (SSAP-SDGs 2017).

Since its establishment, the SSAP-SDGs has developed a roadmap for the implementation of the SDGs in Nigeria focusing on six thematic areas of policies, institutions, data management, partnership, communications, and finance. This implementation programme is intended to be carried out in three phases, i.e. Phase 1:2016-2020, Phase 2: 2020-2026, Phase 3: 20262030 (Mcdickson 2016). The first phase aims at building on the existing foundations. This initial stage is to determine the ultimate trajectory of the programme by establishing effective institutions and innovative policies, and ensuring political buy-in and integration of the SDGs into national and sectoral policy frameworks. The second phase which is the longest phase is 
to focus on scale-up and implementation. i.e. the full implementation of the role of the institutions to monitor implementations agenda and policies. The last phase is the final years of the programme and it is to ensure the full coverage in the most challenging areas and that no person is left behind (Nigeria's Road to SDGs 2015).

The SSAP-SDGs has enjoyed partnership and support of some international institutions such as the United Nations Development Programme (UNDP), United Nations Educational, Scientific and Cultural Organisation (UNESCO), the United Kingdom Department for International Development (DFID), United Nations Millennium Campaign (UNMC), Civil Society Organisation (CSO), the Earth Institute of Columbia University and the United Nations Institute for Training and Research (UNITAR).

However, despite the considerable efforts that might have been made by the implementing actors to sensitise the public about the activities of the SDGs, it appears that the level of awareness and knowledge of Nigerians in the programme is still very low. For instance, in the research conducted among Senior Secondary Students in Rivers State, Nigeria, Njoku observes as follows: ' $78 \%$ of the respondents have not heard of the concept "sustainable development" before and do not understand what it means and how they could contribute.' (Njoku 2016:36; Ifegbesan et al 2017). The next section of this paper addresses this concern.

\section{SDGs and sensitisation of the Nigerian public}

In comparison with other emerging economies like South Africa (Republic of South Africa Millennium Development Goals: Country Report 2015), one of the gaps that were observed about the MDGs programme in Nigeria was that being a people-oriented programme, it failed to reach the targeted groups. There was evidence of many, particularly women and youth that were left behind in the MDGs programme (African Development Report 2015). For instance, according to the report of the National Bureau of Statistics (NBS), the literacy rate of 15-24 years old witnessed a slow progress. It was from $64.1 \%$ in 2000 to $80 \%$ in 2008 ; bounced to $65.6 \%$ in 2011 and stepped up to $66.7 \%$ in 2014 as against the $100 \%$ target of 2015 (NBS 2015,Durokifa and Abdul-wasi2016:666). The high rate of unemployment 
among the youths is still prevalent. For instance, in 2015, it was reported that more than 500,000 young Nigerians applied for advertised job for vacancies of only 2,500 at the Nigerian Immigration Service (Ogunniyi 2015:73, Abdulalaziz 2017). Furthermore, women involvement in politics witnessed little changes compared to the proposed target. Statistics showed that women seats in the parliament improved from 3.1 percent in 2000 to 7.5 percent in 2008 and 5.1 percent in 2015 as compared to the 35 percent required target for 2015 (NBS 2009, Federal Ministry of Women Affairs and Social Development 2015, Durokifa and Abdul-wasi 2016, Ajiye 2014). Although, Nigeria has made progress in reducing maternal deaths, the number of women who die during pregnancy or from complications associated with childbirth remains appallingly high. Nigeria continues to experience high rates of maternal deaths and maternal mortality ratio in the world. (USAID Report 2012, Ajiye 2014).

Realising the above limitations, the SDGs programme now aims to get everyone involved and leave no one behind. Consequently, every Nigerian is expected to be sensitised and be involved in the implementation of the goals. This concern has been rightly observed by the SSAP-SDGs that if Nigeria is to succeed in achieving the SDGs, the need for 'all hands to be on deck' cannot be overemphasised. Awareness is thus critical to the success of sustainability initiatives in Nigeria and Africa at large. A glance at the SDGs and the accompanying targets shows a programme that touches on people's daily affairs. It involves people's active and corresponding participations. In recognition of this, the United Nations (UN) recommends to every individual, including the laziest person, as follows:

Change starts with you. Seriously, every human on earth even the most indifferent, the laziest person among us is part of the solution. Fortunately, there are some super easy things we can adopt into our routines that, if we all do it, will make a big difference (United Nations 2016).

This UN Recommendation further lists about forty-two basic activities that individuals can do in the course of a daily routine that can foster the realisation of the goals. The Recommendation states for example:

Save electricity by plugging appliances into a power strip and turning them off completely when not in use, including your 
computer ... Turn off the lights. Your television or computer screen provides a cozy glow, so turn off other lights if you don't need them ... Eat less meat, poultry, and fish for more resources are used to provide meat than plants ... Bike, walk or take public transport. Save the car trips for when you've got a big group ... When you go to a restaurant and are ordering seafood, shop only for sustainable seafood (United Nations 2016).

Since the SDGs programme needs everyone's input to be realised, it is therefore important that a strategy of creating wider public knowledge about the programme needs to be put in place. The network and reach, that is to say, the number of the people, segments of society or regions that should be reached by the agencies of the implementation of the programme is important to its success. Accordingly, in order for Nigeria and Africa to achieve radical and transformative implementation of the SDGs, there must be a paradigm shift in the approach of communicating the SDGs to Nigerians to get them to accept and be involved in the programme.

In the light of the above, the mandate given to the SSAP-SDGs to provide regular sensitisation and advocacy on SDGs activities to the general public is geared towards the right direction and it is accordingly applauded. Thus, in fulfilling this mandate of sensitising the public, the SSAP-SDGs have established a Communication Unit (the Unit). The Unit is, among other functions, to formulate and articulate a dynamic strategy to achieve effective press and public relations function of the SSAP-SDGs. The Unit is also to handle the overall responsibility of projecting the policies, programmes, plans, and activities of the SSAP-SDGs through press releases, statements, press conferences, feature articles, socio-media, pamphlets, brochures, posters, films, photos and journals (OSSAP-SDGs 2017).

However, while the creation of the Unit and its medium of reaching out to the public are welcomed, they may not be the best and most effective way of sensitising most Nigerians in the quickest time and to gain acceptability. In a developing country like Nigeria and most of the other African countries, a political-administrative structure alone as a measure of communicating goals such as the SDGs may not bring the idea of sustainable development into fruition within the limited time required for its implementation. To accelerate awareness and knowledge of citizens about the SDGs therefore, the influence of institutional actors that have strong traction on the people 
should be employed. In this paper, religious leaders are identified as one such actor through which the SDGs awareness can quickly and widely reach Nigerians.

\section{Religious leaders' influence in Nigeria}

Religion is an indispensable phenomenon in Nigeria. All over the country, religion plays an important role in the daily lives of its citizens. The way Nigerians interact with one another, their choice of dressing, food, and politics are mostly affected by religion (Afolabi 2015). According to Atsenuwa, 'Nigerians are deeply religious and overt in their religious practices such that religious invocations have become formally institutionalised as aspects of public life' (Atsenuwa 2016:13). The passion of Nigerians towards the promotion of their religious practices has been further enhanced by sections 38 and 40 of the Nigerian Constitution, 1999 that guarantee the right to freedom of religion and freedom of association respectively.

According to the National Population Commission, Nigeria's population estimate was 182 million in May 2017 (National Population Commission 2017). Within this population context, Christianity and Islam are the de facto religions that most Nigerians are affiliated (Nwauche 2008, Ukah 2015). The Nigerian government does not track religious affiliation in census data, the United States however, quoting the 2012 survey by the Pew Research Center's Forum on Religion and Public Life, estimated the population of the country to be 49.3 percent Christian and 48.8 percent Muslim, while the remaining 2 percent belong to other or no religions (U.S. International Religious Freedom Report 2016). This report suggests that at least 98 percent of Nigerians affiliate to a religion. In addition, an empirical study conducted by the World Values Survey in 2014 further reveals that 97 percent of all Nigerians say that religion is important to them, and whereas, the national government only 39 percent (World Values Survey 2014). This report shows the wide gap of trust Nigerians has in religious institutions than in the political government. These reports also represent a typical pattern across Sub-Saharan Africa (World Values Survey 2014).

It is also worth noting that the confidence of Nigerians in their religious affiliations corresponds concurrently to their confidence in their religious 
leaders. The religious leaders are revered clerics who are held to have received a specific call from God to address spiritual and physical needs of congregates. Religious leaders here include a Christian pastor or priest, a Muslim Imam, an African traditional religious leader, among others. Religious leaders enjoy a high level of trust and legitimacy that no other civil society actors have achieved in Nigeria. An average Nigerian or African has more confidence in his or her religious leader than any political leader. (Falola 2001). Religious leaders are the first place a Nigerian will turn in an emergency and will be prepared to go any length to obey his religious leader. A common notion that has gained acceptance among Nigerians is that it is absurd to challenge or disregard the authority of a religious leader, who is seen as a messenger of God. Almost anything that is said by religious leaders is believed and taken as truth by their followers. This is why someone in the name of being a religious leader can easily induce other people to tie explosives around their bodies and carry out a suicide bombing mission or make them eat grass or lie down so as to walk on them. That is why many people on the account of the respect for a religious leader are sexually and financially abused without talking about it or even admitting it. A practical example that easily comes to mind is the case of one Chukwuemeka Ezenko, popularly known as 'Rev Dr King' of the Christian Praying Band, whose conviction for the murder of a church member was upheld in 2016 by the Supreme Court in the case of "Rev King v State". ${ }^{3}$ Rev King was said to have been sexually exploiting female members of his church through severe physical assaults, yet no member ever complained to the authority of the State. What brought him to light was when he soaked his female minion who was also one of his victims of sexual abuse with petrol and set her ablaze for the offence of fornication.

Reports from other countries within the African continent reveal similar situations as above. In South Africa, for instance, the Commission for the Promotion and Protection of the Rights of Cultural, Religious and Linguistic Communities (the Commission) conducted an investigative study in 2016 following the response to the religious state of affairs in the country. The Commission in its report observed a high level of reverence and support of

3 (2016) 6 Nigerian Weekly Law Reports (Part 1509), p. 529. 
members to their religious leaders. The Commission reported an instance that took place in one of its hearing as follows:

Thousands of Christian women, who were accompanying their religious leader to the hearings were shown ululating and shouting to their religious leader "my father, my father, my father," while others call out "my bishop" and men were shown blowing vuvuzelas and whistle excitedly as they occupied Queens Road in Parktown, Johannesburg. This was after a top-of-the-range black MercedesBenz S65 has just stopped opposite them, triggering this thrilled reaction from the crowd. They scream "my bishop" to their leader... People in black T-shirts bearing the words "I am who God says I am" were shown shouting "my father, my father" to their leader (CRL Report 2016:17).

Religious leaders do not only earn respect and trust from ordinary members of the public but also from the members of the top political class. Some politicians in Nigeria even win elections by riding on the influence of their religious affiliations and support of their religious leaders. For example, the former Nigerian President, Chief Olusegun Obasanjo and the current Vice-President of Nigeria, Prof Yemi Osinbajo, publicly declared that they consulted and sought the approval of a renowned Nigerian Christian cleric, Pastor E.A. Adeboye before agreeing to take up their political offices (Eyoboka and Olatunji 2017). Writing on the influence of religious leaders, Adigwe states:

Our politicians have found it very useful, even more in recent times, to cling to one religious group or the other as if that group were the driving force, or source of their political power, while at the same time wanting all of us to believe that they strive to govern us, or are governing us in the name of God. Political aspirants ... now have "prophets", "imams" and "native doctors and seers" whom they consult regularly, especially in times of crises (Adigwe 2004:252).

The above instances reveal that religious leaders are one of the most flexible and ubiquitous human resources there are. They have wide networks and potency to reach people in the most remote corners, including places where there are no public institutions. In addition, religious leaders have the potentials of influencing other religious actors such as the religious 
authorities and communities, interfaith networks and councils, religious educational institutions, faith-based organisations, and members of their congregations.

Given the above, religious leaders in Nigeria may be seen as change ambassadors whose influence and resources can be harnessed to sensitise the populace in order to realise some of the objectives of the sustainable developmental agenda. In view of this, religious leaders may be motivated and trained to educate, advocate, preach, and promote among themselves and their followers the broader initiatives of sustainability as a national goal, particularly those aspects of the goals that do not conflict with their religious practices. This is because, a sermon or call by a religious leader to a congregation to accept and get involved in the SDGs agenda will 'speak more volume' than hundreds of press releases, or millions of posters distributed by the SSAP-SDGs. An example of the impact that the influence of religious leaders can have may be drawn from how messages of religious leaders were found useful to curb the Ebola epidemic in some part of West Africa. Deneulin and Zampini write:

During the Ebola outbreak in 2014-2015 in West Africa, national governments and international actors were slow in recognising the significance of religious actors in addressing the outbreak. A report by Christian and Muslim organisations highlights that the religious leaders were able to change messages of fear, based on mere biomedical information from international agencies, into messages of hope and compassion that matched technical and religious perspectives. Due to the trust people have in imams and priests in the region, communities were ready to sacrifice some practices related to burials, such as washing bodies. Unfortunately, the connection between development actors and religious leaders was not as straightforward and as fast as it could have been. More lives could have been saved. (Deneulin and Zampini 2016)

However, to ensure that the relevance of these religious leaders' influence is effectively maximised, it is suggested that the SSAP-SDGs extends the capacity development of stakeholders in the implementation of the SDGs to focusing more on religious leaders at the federal, state and local government levels. This can be done through collaboration with the national and 
regional ecumenical bodies of religious organisations such as the Christian Association of Nigeria and Nigerian Supreme Council for Islamic Affairs or such other similar institutions in the other African States. The SSAP-SDGs can also encourage the religious leaders to incorporate the teaching of basic sustainable principles in the academic curriculum for the training of their leaders. A manual or guide on the implementation of basic sustainable principles can as well be put together for religious leaders.

With more religious leaders getting taught from theological and Koranic schools with an enhanced understanding and insight of the Biblical and Koranic basis of sustainable development, including training of African traditional religion practitioners, more religious clerics will teach about sustainable initiatives, and more Nigerians will become conscious about how to adopt sustainable practices.

The SSAP-SDGs can also seek partnership with religious international organisations that are involved in the promotion of sustainable development practices like the German International Partnership on Religion and Sustainable Development to facilitate this process. An example can be drawn from the German project in Algeria where supports were provided for Islamic clerics who worked with the government representatives to draft position on environmental protection. This resulted in a handbook for the training of imams on the role of a mosque for environmental education. The handbook is now said to be used to teach a new subject of "Biodiversity" that was introduced at Koranic schools (GFMECD 2016). A similar effort was also deployed in Mauritania where it has been possible to get Muslim scholars to support the fight against female circumcision with a view to protecting women and girls (GFMECD 2016).

However, as much as the collaboration with religious institutions may be recognised as a good idea towards the realisation of the SDGs, it is not without its limitations. A few of them would now be considered.

\section{Limitations}

In spite of the above positive influence that religious leaders may have in sensitising the general public about the sustainable initiations. This proposal may not be without its challenges. 


\section{Balancing religious freedom and SDGs}

One of the major reasons why SSAP-SDGs collaboration with the religious leaders is essential is to balance religious views and practices that may appear to conflict with the SDGs principles.

As was observed before, the Nigerian Constitution, for instance, guarantees the rights to freedom of religion and freedom of association. Section 38 subsection 1 of the Constitution provides:

Every person shall be entitled to freedom of thought, conscience, and religion, including the freedom to change his religion or belief, and freedom (either alone or in community with others, and in public or in private) to manifest and propagate his religion or belief in worship, teaching, practice and observance.

Section 40 also provides:

Every person shall be entitled to assemble freely and associate with other persons, and in particular he may form or belong to any political party, trade union or any other association for the protection of his interests.

These provisions allow Nigerians to practice their religion individually or in association with others. The provisions further entitle a religious institution to legitimately regulate and administer its internal affairs within the limits of the law without interference by outside forces, including agencies of the state. (Vyver 2012) In other words, states and courts are expected to respect the identity of religious organisations and give recognition to their religious autonomy and practices (Baeza 2005). According to Witte, internal affairs of a religious organisation will include the power to promulgate and enforce internal religious laws, tenets and practices, and maintain institutions of worship and rituals, and the like (Witte 1993:24).

The concern here is that religious and cultural beliefs have been pinpointed as constituting some of the major obstacles to the sustainability agenda (GFMECD 2016, Joseph 2012). Some key issues that sustainability principles address are undoubtedly rooted in certain religious beliefs and practices. For instance, female circumcision, gender inequality, environmental degradation, human rights abuses, religious and animal rituals, polluting 
the land and the marine, to mention but a few. For example, the Goal 16 of the SDGs seeks to promote peaceful and inclusive societies for sustainable development, provide access to justice for all and build effective accountable and inclusive institution at all levels. The context of this goal may include the promotion of equality and acceptance of people of different religious and sexual orientations like gay and bisexual people or at least, imply more equal and fair treatment. This would be difficult for African religious leaders including Christian and Moslem leaders to accept. These institutions are generally homophobic and quite damning of homosexuality.

In view of the above, achieving sustainable development agenda will require a change not only in goals but also in some values, mindsets, practices, and ethical principles found in some of the religious traditions. However, an attempt to make a policy or, to forcefully require religious institutions to halt some of their religious practices that conflict with the SDGs initiatives may be taken as an infringement of the right of autonomy of the religious institutions to exercise their constitutional rights to freedom of religion. This may result in restraint and affect the acceptability of the sustainability initiatives among the religious communities. Accordingly, Justice Kawu warns:

It is also necessary that in the promulgation of laws for the society, adequate account must be taken of religious interests and beliefs. The violation and suppression of religious rights recognised and guaranteed by law and the exercise of religious rights in total disregard for law and the interests of people of other faiths in a pluralistic world can only lead to chaos, violence, and disruption of society with mankind being the loser (Kawu 2016:1).

Following the above, undertaking a religious reorientation for members of a religious community to change their religious practices and to embrace sustainable practices may be an onerous task for the implementing actors.

\section{Religious economy}

Another major challenge is that in recent time, there are notions from some commentators (Oshikoya 2018) and scholars (Kalu 2007; Abioje 2011; Ukah 2015) that many religious leaders are interested in economic gains as against any altruistic or religious purpose. It is also argued that some 
religious leaders are corrupt, particularly with their fraternisation with politicians. Ukah, for instance, in justification of his religious economic theory in Nigeria argues that Nigerian megachurches have turned into business empires led by 'prophets for profit', business-minded religious entrepreneurs. According to him, these 'prophets for profit' adopt marketing strategies to mobilise and organise funds; they would act as 'economic missionaries' with a prime interest in generating rent instead of supporting spiritual aims. (Ukah 2005). Thus, the implication of this notion is that since there is hardly any direct economic benefits accruable to religious leaders when participating in the SDGs, many religious leaders might not be interested. This concern is, however, a call to the Nigerian churches to conduct a self-check and do the necessary in-house cleansing in order to represent the good image of Christ and be seen as trustworthy to be reposed with responsibilities that will enhance human well-being.

\section{Conclusion}

This paper considered the implementation of the SDGs within the Nigerian context. It stresses that the SDGs programme should not be allowed to go the way of the MDGs by not fulfilling its targets. To make this a reality, the implementing actors need to take pragmatic steps towards sensitising the Nigerian public. The political administrative system as medium of communication of these goals cannot bring the idea of sustainable development into fruition alone. Therefore, collaboration with stakeholders and institutions that have traction on the people of Nigeria should be encouraged. Religious leaders have been identified has one of the institutional actor and stakeholders within the civil society that possess such influence that can easily be harnessed to reach out to wider Nigerians and Africans in general. Given the influence of religious leaders among Nigerians, SSAP-SDGs can focus more on capacity building and dialogue with the religious leaders to harness their influence in this regard, particularly in areas where the SDGs do not conflict with their religious beliefs. Partnership with religious leaders can bring rapid awareness, facilitate public acceptance and involvement, and most importantly, reduce the likelihood of making policies that will breach the right of religious autonomy of religious institutions. 
However, collaboration with religious leaders is not an idea without its challenges because of the resistance they may be put forward where the sustainable principles conflict with religious beliefs. Consequently, other stakeholder groups such as school teachers and lecturers could also be considered for capacity building towards increasing awareness of the programme.

\section{References}

Abdulalaziz, A. 2017. "1.2 Million Applicants Jostle for 1112 Nigeria Immigration Jobs." Premium Times, August 2.

Abioje, P. O. 2011 “A Critique of Commercialization of Religions in Nigeria via the Mass Media”, Ilorin Journal of Religious Studies 1(2): $57-80$.

Adekoya, R. A. A. 2013. “The Diocese of Lagos West of the Anglican Communion, Church of Nigeria as Agent of Social and Political Change in the Society." $\mathrm{PhD}$ thesis, Bangor University, Wales.

Adigwe, H. A., 2004. "Dialogue and Proclamation as the Mission of the Church" in F. A. Adedara, Ed., Church Leadership and the Christian Message. Stirling-Horden: Lagos, Nigeria.

Afolabi, O. O. 2015. “The Role of Religion in Nigerian Politics and its Sustainability for Political Development.” Net Journal of Social Sciences 3(2): 42-49.

African Development Bank. 2016. African Development Report 2015 Growth, Poverty and Inequality Nexus: Overcoming Barriers to Sustainable Development. Development Research Department: ADB, Abidjan.

Ajiye, S. 2014. "Achievements of Millennium Development Goals in Nigeria: A Critical Examination." International Affairs and Global Strategy 25: 24-36.

Heuser, A. 2016 "Charting African Prosperity Gospel Economies”. HTS Teologiese Studies/Theological Studies 72(1): 1-9. 
Atsenuwa, A. 2016. "Religious Pluralism and the Situation of Religious Rights in Nigeria." Paper presented at the $23^{\text {rd }}$ Symposium on "Law and Religion," International Centre for Law and Religion, Brigham Young University Provo, Utah, 1-4 October 2016.

Baeza, S. 2005. "Sheep in Wolves' Clothing: Why Legislation is Necessary to Help Prevent Child Sexual Abuse in Churches." Whittier Journal of Child and Family Advocacy 4: 441-466.

Constitution of the Federal Republic of Nigeria, 1999.

Commission for the Promotion and Protection of Rights of Cultural, Religious and Linguistic Communities in South Africa. 2016. CRL Rights Commission's Preliminary Report of the Hearings on Commercialisation of Religion and Abuse of People's Belief Systems. Johannesburg: South Africa.

Deneulin, S. and Zampini-Davies, A. 2016: "How the Sustainable Development Goals (SDGs) can engage with Religion." The London School of Economics and Political Science. [Online]. Available: http:// blogs.Ise.ac.uk/religionpublicsphere/2016/10/how-the-sustainable-development-goalssdgs-can-engage-with-religion/ [Accessed: 17 August 17 2017].

Durokifa, A. A. and Abdul-wasi, B. M. 2016. "Evaluating Nigeria's Achievement of the Millennium Development Goals (MDGs): Determinants, Deliverables, and Shortfalls." Africa's Public Service Delivery and Performance Review 656-683.

Easterly, W. 2009. "How the Millennium Development Goals are Unfair to Africa." World Development 37(1): 26-35.

Eyoboka, S. and Olatunji, D. 2017. "Like Obasanjo, I Consulted Adeboye before Becoming Vice-President Osinbajo". Vanguard. 16 August 2017.

Falola, T. 2001: Violence in Nigeria: The Crisis of Religious Politics and Secular Ideologies. University of Rochester Press: Rochester, New York. 
Federal Ministry of Women Affairs and Social Development.

2014. Nigeria's Combined Seventh and Eight Reports on the

Implementation of the Convention on the Elimination of All Forms of

Discrimination against Women. Abuja, Nigeria.

Fehling, M. Nelson, B. D. and Venkatapuram, S. 2013. "Limitations of the Millennium Development Goals: A Literature Review.” Global Public Health 8(10): 1109-1122.

German Federal Ministry of Economic Cooperation and Development (GFMECD). 2016. Religious Communities as Partners for Development Cooperation. BMZ: Germany.

Gurbo, M. 2017. Why are Sustainable Development Goals Important: Supporting the Implementation of UN Sustainable Development Goals in Georgia Project. Institute for Development of Freedom of Information: Geogia, US.

Hickel, J. 2015. “The Problem with Saving the World.” [Online]. Available: https://www.jacobinmag.com/2015/08/global-poverty-climate-change-sdgs/ [Accessed: 17 August 2017].

Ifegbesan, A. P. Lawal, M. B. and Rampedi, I. T. 2017. “The Nigerian Teachers Social Studies Training Curriculum and Sustainable Development Goals: A Content Analysis." Journal of International Social Studies 7(1): 92-122.

Joseph, Y. 2012. "Faith and Sustainable Development: An African Christian perspective" [Online]. Available: http://earthcharter.org/invent/ images/uploads/13\%20Manuscrip_Yakubu.pdf [Accessed: 25 August 2017].

Kalu, O. U. 2007. "The Big Man of the Big God Popular Culture, Media, and the Marketability of Religion". New theology Review 15-26.

Kawu, D. 2016. "Religious Right in a Pluralistic World: The Nigerian Experience." Paper Presented at the $23^{\text {rd }}$ Symposium on "Law and Religion". International Centre for Law and Religion, Brigham Young University Provo, Utah. 1-4 October 2016.

McDickson, J. 2016. "Sustainable Development Goals (SDGs) The Nigerian Way." [Online]. Available: http://sdgs.gov.ng/sustainabledevelopment-goals-sdgs-nigerian-way/ [Accessed: 24 August 2017]. 
Munang, R. and Andrews, J. 2014. “The Next Steps: Africa's Sustainable Development Goals and Their Implications.” Environment: Science and Policy for Sustainable Development 56(5):1-9.

National Bureau of Statistics. 2014. Quarterly GDP Report. NBS, Abuja, Nigeria.

National Bureau of Statistics. 2015. Millennium Development Goals Performance Tracking Survey Report. NBS: Abuja, Nigeria.

Nigerian National Population Commission. 2017. "Nigeria's population now 182 million.” [Online]. Available: www.population.gov.ng/nigeriaspopulation-now-182-million-npc/ [Accessed: 20 November 2017].

"Implementing sustainable goals in Nigeria". Nigerian Pilot. 21 August 2016.

United Nations Development Programme. "Nigeria's Road to SDGs: Country Transition Strategy October 2015”. [Online]. Available: http:// www.ng.undp.org/content/dam/nigeria/docs/lclusiveGrwth/Nigeria\%20transition\%20 strategy\%20to\%20SDGs.pdf [Accessed: 30 May 2018].

Nilsson, M. and Costanza, R. 2015. "Overall Framework for the Sustainable Development Goals." Review of Targets for the Sustainable Development Goals: The Science Perspective, International Council for Science (ICSU), Paris.

Njoku, C. 2016 "Awareness of Climate and Sustainability Development Issues among Junior Secondary School (JSS) Students in Port Harcourt Metropolis of River State, Nigeria.” International Journal of Curriculum and Instruction 8(2): 29-40.

Nunes, A. R., Lee, K. and O'Riodan, T. 2016. “The Importance of an Integrating Framework for Achieving the Sustainable Development Goals: The Examples of Health and Well-being." BMJ Global Health $1-13$.

Nwauche, E. 2008. "Law, Religion and Human Rights in Nigeria." African Human Rights Law Journal 8: 568-595. 
Office of the Senior Special Assistant to the President on Sustainable Development Goals. 2017. “Our Mandate”. [Online]. Available: http:// sdgs.gov.ng/about-sdgs/our-mandate/ [Accessed: 24 August 2017].

Office of the Senior Special Assistant to the President on Sustainable Development Goals. 2017. Millennium Development Goals End-Point Report 2015. [Online]. Available: http://www.ng.undp.org/content/dam/ nigeria/docs/MDGs/Nigeria_MDG_Report\%202015\%20Full\%20Repot.pdf [Accessed: 24 August 2017].

Office of the Senior Special Assistant to the President on Sustainable Development Goals. 2017. Unit- Communication Unit. [Online]. Available: http://sdgs.gov.ng/about-sdgs/units/\#comm [Accessed: 29 July 2017].

Ogunniyi, O. J. 2015. "Millennium Development Goals in Nigeria. Issues and Prospects: An Historical Paradox." Sarajevo Journal of Social Sciences. Inquiry 2:65-74.

Oleribe, O. O. and Taylor-Robinson, S. D. 2016. "Before Sustainable Development Goals (SDGs). "Why Nigeria Failed to Achieve the Millennium Development Goals (MDGs).” The Pan African Medical Journal 24:156-161.

Oshikoya, O. "Omilola Oshikoya Writes Open Letter to Daddy Freeze on the Subject of Tithing” at Bella Naija's Blog [Online]. Available: https:// www.bellanaija.com/2018/04/omilola-oshikoya-writes-open-letter-daddy-freezesubject-tithing/ [Accessed: 27 May, 2018].

Saith, A. 2017. "Goals Set for the Poor, Goalposts Set by the Rich.” Institute of Asian Studies Newsletter- Development Discourse 45.

Ukah, A. 2005. “Those Who Trade with God Never Lose: The Economics of Pentecostal Activism in Nigeria", in T. Falola ed., Christianity and Social change in Africa: Essays in honor of J.D.Y. Peel: Carolina Academic Press, Durham, NC. pp. 253-274,

Ukah, A. 2015:“Obeying Caesar to Obey God: The Dilemmas of Registration of Religious Organisations in Nigeria” in P. Coertzen et al, eds., Law and Religion in Africa: The Quest for the Common Good in Pluralistic Societies: African Sun Media, Stellenbosch, pp. 309-329. 
United Nations. 2015. Transforming Our World: The 2030 Agenda for Sustainable Development, accessed October 11, 2017 fromhttp://www. un.org/ga/search/view_doc.asp?symbol=A/RES/70/1\&Lang=E.

United Nations. 2015. The Millennium Development Goals Report 2015, United Nations, Department of Economic and Social Affairs of the United Nations, accessed August 17, 2017 from http://www.un.org/ millenniumgoals/2015_MDG_Report/pdf/MDG\%202015\%20rev\%20(July\%201).pdf.

United Nations. 2015. Consensus Reached on New Sustainable Development Agenda to be adopted by World Leaders in September, accessed August 17, 2017 fromhttp://www.un.org/sustainabledevelopment/ blog/2015/08/transforming-our-world-document-adoption/.

United Nations. 2016.The Lazy Person’s Guide to Saving the World, accessed at: http://www.un.org/sustainabledevelopment/takeaction/ (29 July 2017)

U.S. Department of State. 2016. International Religious Freedom Report for 2016.Washington DC.

USAID Nigeria. 2012. ACCESS/MCHIP Evaluation. Abuja, Nigeria.

Van der Vyver, J. D. 2012. "Equality and Sovereignty of Religious Institutions: A South African Perspective."Santa Clara Journal of International Law10: 147- 169.

Witte, J. 1993. “The South African Experiment in Religious human Rights: What can be Learned from the American Experience" Journal for Juridical Science 18(1): 1-32.

World Values Survey. 2014. World Values Survey Wave 6: 2010-2014, accessed October 11, 2017 fromwww.worldvaluessurvey.org/WVSOnline.jsp

Wysokinska, Z. 2017. "Millennium Development Goals/UN and Sustainable Development Goals/UN as Instruments for Realising sustainable Development Concept in the Global Economy." Comparative Economic Research 20(1): 101-118. 